(C) 1998 The Chemical Society of Japan

\title{
有機溶媒中でのリパーゼ触媒によるトリブチリルグリセリンと 2-オクタノールとのエステル交換におけるエナンチオ選択性
}

(1997 年 8 月 21 日受理)

\author{
平田博文*.宮岸正人・間山素美
}

トリブチリルグリセリン(1) と 2-オクタノール(2) とのエステル交換を Pseudomonas cepacia リパーゼ $(\mathrm{PCL}), 8$ 種の有機溶媒を用い, $10-70^{\circ} \mathrm{C}$ で検討した. エナンチオ選択性 $\log E(E$ は 2 のエナンチオ マーの速度比を示す $)$ と溶媒の疎水性 $\log P(P$ は溶媒のオクタノール-水への分配係数を示す) との相関

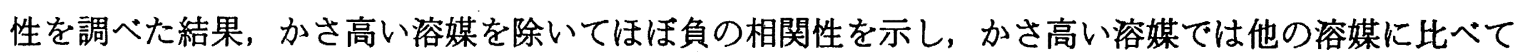
$\log P$ から期待されるよりも低いエナンチオ選択性を示した．この相関性は反応温度によって変化する ことを認めた．かさ高い溶媒では反応温度の上昇とともに $\log E$ 值は増大したが, ヘブタンではほほ一 定であり，他の溶媒では減少した．かさ高い溶媒中の反応では $\Delta \Delta H^{\ddagger}$ 值 $[(R)$ 体と $(S)$ 体の活性化エン タルピーの差]は正であったが, 他の溶媒中では負の值を示した. 前者の $\Delta \Delta S^{\ddagger}$ 值 $[(R)$ 体と $(S)$ 体の活 性化エントロピーの差]は後者の場合よりむ大きかった. 以上の結果から， PCLによる 1 と 2 とのエス テル交換のエナンチオ選択性は溶媒の性質・構造および反応温度の組合せに依存することがわかった. また，PLCの活性サイトモデルを考え，それによる解釈も試みた.

\section{1 緒 言}

近年, 有機溶媒中におけるリパーゼ(EC 3.1.1.3)による酸やア ルコールの光学分割に関する論文が数多〈報告されている(1)-3). これはリパーゼが有機溶媒中で安定かつ触媒活性を保持するこ と4)5，基質特異性が広く種々の化合物の反応を触媒すること2)3), さらに，エナンチオ選択性の良いリパーゼが入手できることなど による. 有機溶媒中に抢けるリパーゼ触媒による反応のエナンチ 才選択性は基質36)，溶媒677，温度 ${ }^{83}$ によって変化することが知 られているが, その相互の関係性については研究されていない. そこで本報では，Pseudomonas cepacia リパーゼ(PCL)によるト リブチリルグリセリン[トリブチリン(1)]と 2-オクタノール(2) とのエステル交換(Scheme 1)を選び，8種の有機溶媒を用い，

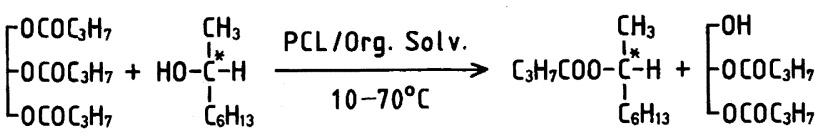

$$
\begin{aligned}
& 12 \\
& 3
\end{aligned}
$$

Scheme 1 Lipase catalyzed transesterification between tributyrylglycerol (1) and 2-octanol (2) in organic solvents.

PCL: Pseudomonas cepacia lipase (Lipase PS, Amano, $43 \mathrm{U} / \mathrm{mg}), 3:(R)-1$-methylheptyl butyrate, 4: 2,3-dibutyrylglycerol (Dibutyrin).

北海道東海大学工学部生物工学科, 005 札幌市南区南沢 5-1
エナンチオ選択性の溶媒抢よび温度 $\left(10-70^{\circ} \mathrm{C}\right)$ 依存性の相関性 を調べるととるに，活性化パラメーター $\left(\Delta \Delta H^{\ddagger}, \Delta \Delta S^{\ddagger}\right)$ の評価を 行った. さらに, 得られた活性化パラメーターから活性サイトモ デルを考え, 活性サイトに及ほすす溶媒の効果を考察した。

\section{2 実験}

\section{1 原料}

1(GR，和光純薬)はモレキュラシーブ(3A $1 / 16$, 和光純薬) で 脱水・乾燥したものを, $2(\mathrm{GR}$, 東京化成), $(R)$-および $(S)-2-$ オクタノール[(R)-抽よ゙ $(S)-(2)$, チッソ化学, 光学純度 $e e>$ 99\%], (R)-1-(1-ナフチル)エチル=イソシアナート[( $R)-\mathrm{NEI}]$ (Aldrich), PCL(Lipase PS, $43 \mathrm{U} / \mathrm{mg}$, 天野製薬), シリカゲル (Silica gel 60，70-230 mesh, 片山化学)は市眅品をそのまま用 いた. 溶媒は常法9 に従って精製した後，モレキュラシーブで脱 水・乾燥したものを用いた.

\section{2 反 応}

$0.50 \mathrm{M}\left(1 \mathrm{M}=1 \mathrm{~mol} \mathrm{dm}^{-3}\right)$ の $1,0.54 \mathrm{M}$ のを含む基質溶液

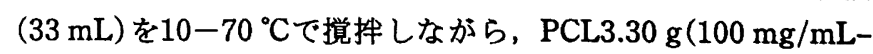
sub. soln.)を加えて反応を開始した. 経時変化を追跡しながら反 応進度 $c=0.2-0.3$ 達したところで沪過により反応を停止し， $\mathrm{PCL}$ 粉末を $20 \mathrm{~mL}$ のベンゼンで 2 回洗浄した、水難溶性溶媒の 場合は，汇液を合わせ，100 g のシリカゲルを充媜したカラム $(\phi 30 \mathrm{~mm})$ に負荷し，化合物をベンゼン $(800 \mathrm{~mL}) \rightarrow$ タノール $(300 \mathrm{~mL})$ で溶出した．水溶性の溶媒(シオキサン，アセトニトリ ル)の場合は洰液にベンゼン $(300 \mathrm{~mL})$ を加え，水洗 $(100 \mathrm{~mL} て ゙$ 
3 回)，無水硫酸ナトリウムで脱水，エバポレーターで濃縮後， 残留物 $(7-9 \mathrm{~g})$ にベンゼン $(30 \mathrm{~mL})$ を加えてシリカゲルカラムに 負荷し，水難溶性溶媒の場合と同様の処理を行った.

エステル画分 $(300-600 \mathrm{~mL}$ のフラクション)を合わせ，エバ ポレーターで溶媒を除去すると目的の $(R)-1$ メチルヘプチル ブチラート $[(R)-(3)]$ が得られた。純度 $>99 \%$ (GC から), 収率 : $75-85 \%$.

上記で得られたエステル $(R)-3 に 1 \mathrm{M} \mathrm{KOH} / 10 \% \mathrm{H}_{2} \mathrm{O}-\mathrm{C}_{2} \mathrm{H}_{5}$ $\mathrm{OH}(10 \mathrm{~mL} / \mathrm{g}$ 一エステル)を加え，30-60 $\mathrm{min}$ 還流あるいは室温 で $24 \mathrm{~h}$ 反応させた．反応混合物に飽和食塩水 $100 \mathrm{~mL}$ を加え， ヘキサン $(30 \mathrm{~mL}$ で 3 回)で抽出, 飽和食塩水 $(20 \mathrm{~mL}$ で 3 回)洗 浄, 無水硫酸ナトリウムで脱水後, エバボレーターで溶媒を除去

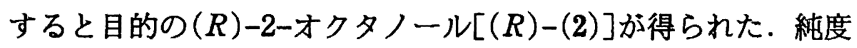
$>99 \%$ (GC から), 収率 $[(R)-3$ を基準として $]: 60-70 \%$.

アルコール画分 (メタノール溶出部)には未反応の1 の他に反 応に伴って生ずるジブチリルグリセリン(ジブチリン)(4)が含ま れていた(GCで確認)が，これらは以下の処理により除去でき た. アルコール画分をエバポレーターで濃縮後, 残留物(5-6 g) に $1 \mathrm{M} \mathrm{KOH} / 10 \% \mathrm{H}_{2} \mathrm{O}-\mathrm{C}_{2} \mathrm{H}_{5} \mathrm{OH}$ を $50 \mathrm{~mL}$ 加え, 室温で $24 \mathrm{~h}$ あ るいは50 ${ }^{\circ} \mathrm{C} て ゙ ~ 3-5 h$ 反応させた後, エステル画分と同様の処理

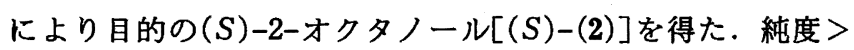
99\%(GCから), 収率 : 60-70\%。

\section{3 分析方法}

GC 分析は日立 263-80 型ガスクロマトグラフ(検出器 : FID) を用いて行った. カラム: G-100カラム (日本食品検查協会), $\phi 1.2 \mathrm{~mm} \times 20 \mathrm{~m}$, 液厚 $1.0 \mu \mathrm{m}$. カラム温度 : $80 \rightarrow 250{ }^{\circ} \mathrm{C}, 10^{\circ} \mathrm{C} /$ $\min$ 昇温, 注入口温度: $270^{\circ} \mathrm{C}$, キャリヤー $\left(\mathrm{N}_{2}\right): 20 \mathrm{~mL} / \mathrm{min}$.

HPLC 分析は日本分光インテリジント HPLC システム(波長 可変型 UV 検出器) を用いて行った. カラム : Finepak SIL (日本 分光) $\phi 4.6 \times 250 \mathrm{~mm}$, 粒径 $5 \mu \mathrm{m}$, 移動相 : $0.05 \mathrm{vol} \%$ のタノ 一ルを含むジクロロメタン, 検出波長 : $254 \mathrm{~nm}$, 流速 : $1.0 \mathrm{~mL} /$ $\min$.

2.2で得られたアルコール[生成物 $(R)-3$ のアルコール残基お よび末反応アルコール $(S)-3]$ の光学純度 $(e e)$ は前報10)の方法で

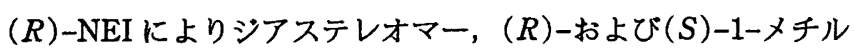

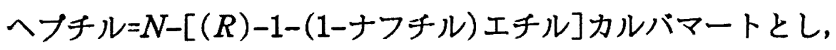
クロマトグラムの面積百分率から計算した.

水分測定は三菱 CA-06 電量滴定型水分測定器を用いた. PCL の水分量は $1.65 \mathrm{wt} \%$, 基質溶液の水分量は0.01 vol\%以下であっ た.

\section{3 結果と考察}

\section{1 エナンチオ選択性の溶媒一温度依存性}

醥素法による動力学的分割の理論2)11)によれば, 平衡定数が小 さく, かつ, 反応進度 $c$ が小さいところでは逆反応が無視でき不 可逆的競争反応とみなされ2)12)，ラセミ体中のエナンチオマーの 速度比 $E$ (これをエナンチオ選択性とも呼ぶ)は

$$
\begin{aligned}
E & =\frac{\ln \left[1-c\left(1+e e_{\mathrm{P}}\right)\right]}{\ln \left[1-c\left(1-e e_{\mathrm{P}}\right)\right]} \quad\left(=E_{\mathrm{P}}\right) \\
& =\frac{\ln \left[(1-c)\left(1-e e_{\mathrm{S}}\right)\right]}{\ln \left[(1-c)\left(1+e e_{\mathrm{S}}\right)\right]} \quad\left(=E_{\mathrm{S}}\right)
\end{aligned}
$$

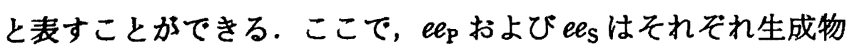

および未反応基質の光学純度 (鏡像体過度, $0 \leqq e e \leqq 1$ )を示す.

ここで，不可逆条件を満たすためには，上式から求めた $E$ 值 が $c$ 值に無関係に一定であることが必要である2)11)12). そこで, $[1]=0.32-0.87 \mathrm{M},[2]=0.16-0.75 \mathrm{M},[1] /[2]=0.5-1.8$ で $E$

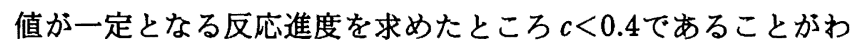
かった． また， $E_{\mathrm{P}}=E_{\mathrm{S}}$ も成立していた．したがって，以下の実 験では $[1]=0.50 \mathrm{M},[2]=0.54 \mathrm{M}, c=0.2-0.3$ 条件下で行い, 式(1), (2)から $E$ 値を求めた.

リパーゼによるエナンチオ選択性の溶媒依存性は主に溶媒の疎 水性 $\log P$ (ここで， $P$ は溶媒のオクタノールー水への分配係数を 示す) ${ }^{13)}$ を尺度として検討されている67)14)-17). そこで最初に， エステル交換の $\log E$ と $\log P$ との相関性を $10,70^{\circ} \mathrm{C}$ で検討し た. 結果は Fig. 1 に示す通りであった．この図からエナンチオ 選択性 $(\log E)$ はいずれの温度ですジオキサン, シクロヘキサン, 四塩化炭素のようなかさ高い溶媒を除いて $\log P$ とほほ負の相関 性を示し, かさ高い溶媒では他の溶媒に比へて $\log P$ から期待さ れるよりむ低いエナンチオ選択性を示すことがわかった．また， $\log E$ と $\log P$ との相関性は反応温度によってむ変化することが 認められた.

本報でかさ高い溶媒とは分子の長軸に垂直な断面積が大きい溶 媒を意味する．例えば, ヘプタンとシクロヘキサンとを比較する と分子の長軸はへプタンの方が長いが, 断面積はシクロヘキサン 環(六員環)を有するシクロヘキサンの方が大きい，同様に，シオ キサンむかさ高い溶媒に属する. 四塩化炭素の場合, 原子半径の 大きい塩素原子が 4 個結合しているため，断面積が大きい。べ ンゼンやトルエンは六員環を有するが, ベンゼン環は平面構造の ため断面積は小さい. アセトニトリルの断面積はへプタンと同等 かそれより小さいと考えられる. また，分子の両末端に塩素原子 を有する 1,2-ジクロロエタンは四塩化炭素よりむ断面積は小さ く,ヘフタタンやアセトニトリルよりむ断面積は大きいと考えられ るが, $E$ 值が他の溶媒中よりも大きいことから, 断面積の小さい

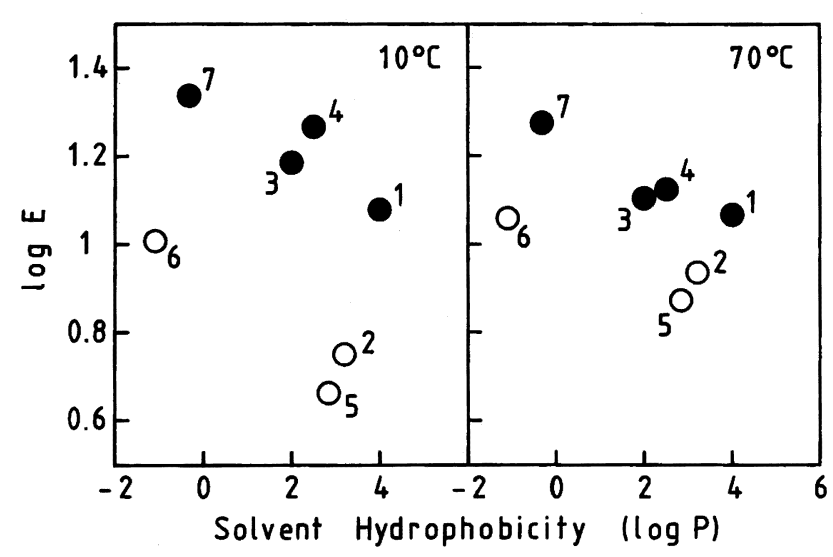

Fig. 1 Plots of $\log E$ against $\log P$ for PCL catalyzed transesterification between tributyrylglycerol (1) and 2-octanol (2) in organic solvents.

$E$ is the enantiomeric ratio and $P$ is a partition coefficient of a given solvent between octanol and water.

Solvents 1: Heptane, 2: cyclohexane, 3: benzene, 4: toluene, 5: carbon tetrachloride, 6 : dioxane, 7 : acetonitrile. 
溶媒に属すると考えた．以上のことから，Fig. 1 のかさ高い溶媒 分子の溶媒中の $E$ 值が他の溶媒中に比へて小さいのは溶媒の立 体障害によるむのであり，その効果が温度により異なることを示 している.

Fig. 1 から得られた実験事実をより詳しく検討するため, 各種 溶媒中でのエナンチオ選択性の温度依存性を調へた．代表的な結 果をFig. 2 に示した.この図からトルエン, 1,2-シクロロエタ ン中では反応温度 $T$ の上昇ととむに $\log E$ が減少することがわ かった．同様の傾向はベンゼン, アセトニトリル中の反応です認 められた。水溶液中における Thermoanaerobacter ethanolicus 由 来の第二級アルコールデヒドロゲナーゼによる 2-ブタノールお よび2-ペンタノールの酸化・還元反応で $T$ が上昇するとエナン チ才選択性が低下することが知られている8b). また，ドデカン 中, ブタすい蔵リパーゼ(PPL)触媒による酢酸ビニルと 6-メチ ル-5-ヘプテン-2-オールとのエステル交換 ${ }^{8 \mathrm{a})}$ で $T$ が上昇すると $E$ 值が减少することが報告されている．これらのことから，一般 に $T$ が上昇すると $E$ 值が低下するむのと考えられる. これとは 異なり，四塩化炭素中では逆に $T$ の上昇とともに $\log E$ が增大 することがわかった．同様の正の傾向は他のかさ高い溶媒である シクロヘキサンおよびシオオキン中におけるエステル交換です認 められた. 他方, Fig. 2 からへプタン中では $\log E$ が $T$ に無関 係にほほ一定であり, 通常の溶媒とかさ高い溶媒との中間の様子 を示した. 前述の定義からへプタンはかさ高い溶媒には属してい ないが，他の溶媒と比較して分子の長軸が長いことを考虑すると， $E$ 值の温度依存性は溶媒分子のかさ高さに加えて容積にす影響さ れるものと考えられる. ドデカンとヘプタンは同種の溶媒である が，Tが上昇すると PPL では $E$ 值が減少し ${ }^{8 a)}$, PCL では一定で ある(Fig. 2). 有機溶媒中における PPLによる 1 と 2 とのエス テル交換では, Fig. 1 とは異なり溶媒のかさ高さとは無関係に

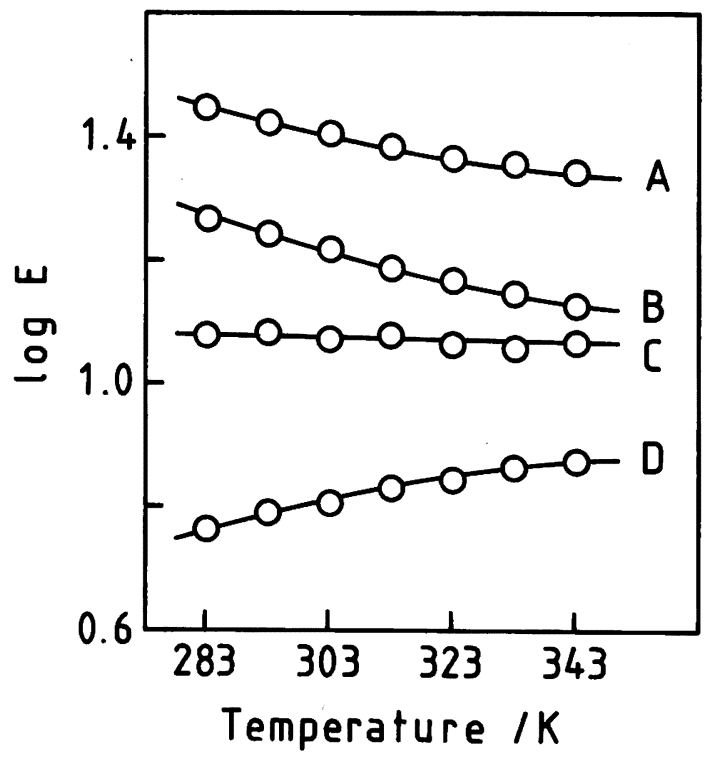

Fig. 2 Plots of $\log E$ against the reaction temperature $(T)$ for PCL catalyzed transesterification between tributyrylglycerol (1) and 2-octanol (2) in organic solvents.

Solvents A: 1,2-Dichloroethane, B: toluene, C: heptane, D: carbon tetrachloride. $\log E$ は $\log P$ と負の相関性を示すことや第二級アルコールとの 反応のエナンチオ選択性の基質・溶媒依存性が異なること䄈か ら PPL と PCL の活性サイト(構造)が異なっているため $E$ 值の 温度依存性が異なっているものと考えられる。

\section{2 活性化パラメーター $\left(\Delta \Delta H^{\ddagger}, \Delta \Delta S^{\ddagger}\right)$ の評価}

3.1で得られた実験事実を論理的に解釈するため, 活性化バラ メーターを求めた. 遷移状態理論を動力学的分割に応用すると, 速度比 $E$ と活性化 Gibbs エネルギー差 $\Delta \Delta G^{ \pm}=\Delta G^{ \pm}(R)-\Delta G^{ \pm}$

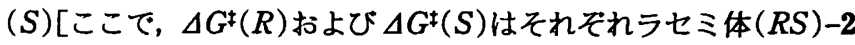
中の $(R)$ および $(S)$ 体の反応の活性化 Gibbs エネルギーを示す] は

$$
\Delta \Delta G^{\ddagger}=-R T \ln E
$$

と表すことができる．ここで， $R$ は気体定数， $T$ は絶対温度を 示す. また, $\Delta \Delta G^{\ddagger}$ と活性化エンタルピーおよび活性化エントロ ピーの差 $\left(\Delta \Delta H^{\ddagger}\right.$ および $\left.\Delta \Delta S^{\ddagger}\right)$ との関係は, 反応温度 $T$ で

$$
\Delta \Delta G^{\ddagger}=\Delta \Delta H^{\ddagger}-T \Delta \Delta S^{\ddagger}
$$

と表すことができる. 本実験では常圧(圧力 $P$ 一定)で反応を行 っているので, $\Delta \Delta G^{\ddagger}$ と $\Delta \Delta S^{\ddagger}$ との間には

$$
\left(\frac{\partial \Delta \Delta G^{\ddagger}}{\partial T}\right)_{\mathrm{P}}=-\Delta \Delta S^{\ddagger}
$$

が成立する。

Fig. 3 に式 ( 3 ) から計算した $\Delta \Delta G^{\ddagger}$ 值の温度依存性の代表例 を示した．この図から $\Delta \Delta G^{\ddagger}$ 値は反応温度 $T$ と良好な負の相関 性があることがわかった. 式(5)から Fig. 3 のブロットの傾き $=-\Delta \Delta S^{\ddagger}$ であり, 式 (4) から $T=0 \mathrm{~K}$ では $\Delta \Delta G^{\ddagger}=\Delta \Delta H^{\ddagger}$ とな る. また, $\Delta \Delta G^{\ddagger}=0$ となる温度 $T_{\mathrm{r}}$ (ラセミ化温度と呼ばれる)は エナンチオマーの反応速度が逆転する温度を示す. 以上の計算結 果を Table 1 に示した. この表からかさ高い溶媒中の反応ではい

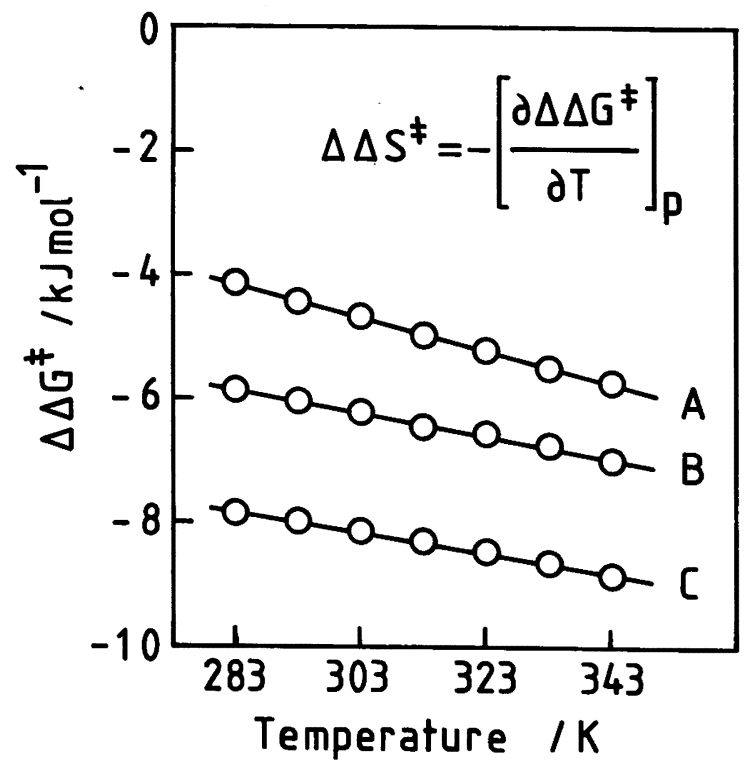

Fig. 3 Plots of difference of activation Gibbs free energy $\left(\Delta \Delta G^{\ddagger}=-R T \ln E\right)$ against the reaction temperature $(T)$ for PCL catalyzed transesterification between tributyrylglycerol (1) and 2-octanol (2) in organic solvents.

Solvents A: Carbon tetrachloride, B: heptane, C: 1,2dichloroethane. 
Table 1 Activation parameters for PCL catalyzed transesterification between tributyrylglycerol (1) and 2octanol (2) in organic solvents

\begin{tabular}{lrrrrr}
\hline \multirow{2}{*}{ Solvent } & \multicolumn{1}{c}{$\Delta \Delta H^{\ddagger}$} & & $\Delta \Delta S^{\ddagger}$ & & \multicolumn{1}{c}{$T_{\mathrm{r}}^{\mathrm{a}}$} \\
\cline { 5 - 5 } \cline { 5 - 5 } \cline { 5 - 5 } & \multicolumn{1}{c}{$\mathrm{kJ} \mathrm{mol}^{-1}$} & & $\mathrm{~J} \mathrm{~K}^{-1} \mathrm{~mol}^{-1}$ & & \multicolumn{1}{c}{$\mathrm{K}$} \\
\hline Heptane & $-0.6 \pm 0.6$ & & $19 \pm 2$ & & $-32 \pm 32$ \\
Cyclohexane & $2.6 \pm 0.2$ & & $25 \pm 2$ & & $102 \pm 12$ \\
Benzene & $-2.5 \pm 0.8$ & & $14 \pm 3$ & & $-184 \pm 28$ \\
Toluene & $-4.5 \pm 0.2$ & & $8 \pm 1$ & & $-530 \pm 17$ \\
Carbon tetrachloride & $3.4 \pm 0.3$ & & $27 \pm 2$ & & $127 \pm 18$ \\
1,2-Dichloroethane & $-3.1 \pm 0.3$ & & $17 \pm 2$ & & $-190 \pm 8$ \\
Dioxane & $1.6 \pm 0.6$ & & $25 \pm 2$ & & $64 \pm 31$ \\
Acetonitrile & $-1.7 \pm 0.3$ & & $20 \pm 2$ & & $-86 \pm 11$ \\
\hline
\end{tabular}

a) The racemic temperature at which $\Delta \Delta G^{\ddagger}=0$.

ずれも $\Delta \Delta H^{\ddagger}>0$ ，すなわち， $T=0 \mathrm{~K}$ では 2 の $(S)$ 体を優先的 に触媒するが，その $T_{\mathrm{r}}$ はいずれも $150 \mathrm{~K}$ 以下と低かった．ま た，他の溶媒中では $\Delta \Delta H^{\ddagger}<0$ かつ $T_{\mathrm{r}}<0$ である. したがって， 通常の反応条件下では PCL は $(R S)-2$ 中の $(R)$ 体を優先的に触

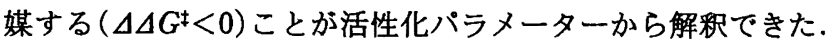
他方, かさ高い溶媒中の反応の $\Delta \Delta S^{\ddagger}$ 値は他の溶媒に比べて大 きい.これはかさ高い溶媒では立体障害があり，Tの上昇とと もに $(R)$ 配位が起こりやすくなり, 活性化エントロビーの一部が 配位エネルギーとして使われることを示唆している．このことは かさ高い溶媒中で $E$ 值が $T$ の上昇とともに大きくなること (Fig. 2) からも支持される. 以上のことから，PCL 触媒による 1 と 2 とのエステル交換ではエナンチオ選択性が溶媒のかさ高さ に影響されることがわかった。

\section{3 活性サイトモデルによる解釈}

3.1，3.2の結果をさらに詳しく説明するために活性サイトモデ ルを考えた. Kazlauskas ら ${ }^{19)}$ は PCL による60 種以上の第二級 アルコールのエステルの加水分解および第二級アルコールのエス テル化，エステル交換の分割データから Fig. 4 に示すような活 性サイトモデルを提案している．しかし，このモデルでは触媒作 用が $(R)$ 体優先であることは説明できるが，本報の他の結果は説 明できない，そこで， subtilisin Carlsberg(EC 3.4.21.14)による 酢酸ビニルと 1-フェニルエタノールとのエステル交換 ${ }^{16)}$, Aspergillus Oryzae プロテアーゼによる $N$-アセチルフェニルアラニン の 1-クロロエチルエステルとプロパノールとのエステル交換 ${ }^{17)}$ および Candida rugosa リパーゼによる 2-ヒドロキシカルボン酸 と第一級アルコールとのエステル化 6 (b) で提案されている活性サ イトモデルを参考として Fig. 5 に示すモデルを考えた : PCL の 活性サイトには large pocket(LP) と small pocket(SP)の 2 個の 結合サイトがあり，(R)配位では 2 のヘキシル基は LP に，メチ ル基は SP に結合し反応が起こる(Fig. 5, R-1). (S) 体では逆の

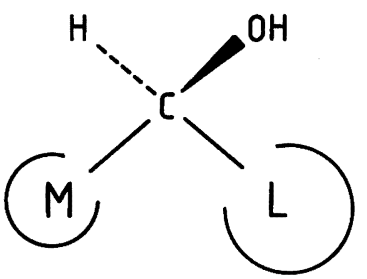

Fig. 4 Active site model of PCL proposed by J. R. Kazlauskas et al. (Ref. 19). This model predicts which enantiomer of secondary alcohol is reacted by PCL.
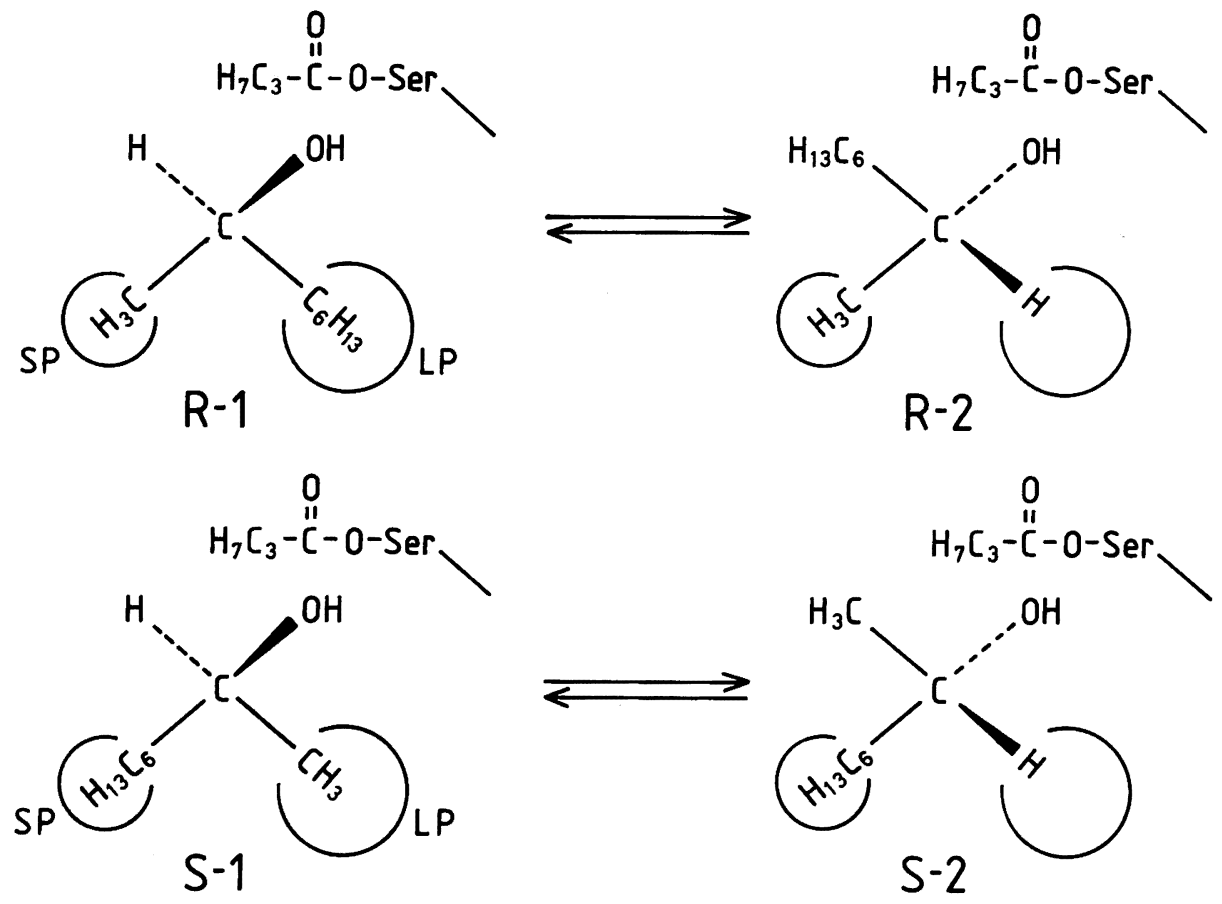

Fig. 5 Proposed active site model for PCL catalyzed transesterification between tributyrylglycerol (1) and 2-octanol (2) in organic solvents.

LP: Large pocket of binding site, SP: small pocket of binding site, R-1: productive mode of $(R)$ isomer, S-1: productive mode of $(S)$ isomer, R-2: nonproductive mode of $(R)$ isomer, S-2: nonproductive mode of $(S)$ isomer. 
結合で反応が起こる(Fig. 5, S-1)．また，それぞれの配位に相当 する反応の起こらない配位(Fig. 5, R-2 および S-2) が存在し， それぞれが可逆(平衡)にあるとした，さらに，溶媒分子は活性サ イトの LP 側に入り込み，活性サイトが広げられることにより反 応が促進されると仮定した。

まず，(R)-2 のメチル基および $(S)-2$ のヘキシル基が SP に 結合してそれぞれ R-2 および S-2 配位となる．次いで， $(R)-2$ のへキシル基拉び $(S)-2$ のメチル基が LP と結合してそれぞ れ結合型の R-1 および S-1 配位となる. その際，溶媒の疎水性 が関係する，すなわち，溶媒の親水性が高くなると疎水性相互作 用が大きくなるが，その大きさはへキシル基の方がメチル基より も大きいため, R-2 $\rightarrow \mathrm{R}-1$ の方が $\mathrm{S}-2 \rightarrow \mathrm{S}-1$ よりも起こり易い. したがって, $\log P$ が小さくなると $E$ 值が大きくなる(Fig. 1).

かさ高い溶媒では， R-2 $\rightarrow \mathrm{R}-1$ および $\mathrm{S}-2 \rightarrow \mathrm{S}-1$ の変化の際, 溶媒分子とへキシル基およびメチル基との立体障害があり，その 大きさはへキシル基>メチル基の順であるため, 他の溶媒よりも $E$ 値が小さくなるものと考えられる.

酵素反応を有機溶媒中, 高温で行うとき溶媒分子の反応阻害や 酵素自体の安定性が問題となる. そこで，エステル交換の経時変 化を( $R S)-2$ と 1-オクタノールについて $30^{\circ} \mathrm{C} て ゙$ 比較したところ, 1-オクタノールでは通常の反応率曲線を描いたが，( $R S)-2$ では 反応性の高いエナンチオマー $(R)-2$ と反応性の低いエナンチオ マー $(S)-2$ が存在するため $c>0.4$ では 1-オクタノールの場合に 比べて反応率の増加が抑えられた。この傾向は本報で用いた 8

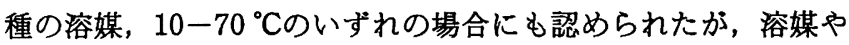
温度による反応率の抑制は認められなかった．有機溶媒中に抢け る PCL による 1 と第二級アルコールとのエステル交換で，四塩 化炭素中で 4-ノナノールは全く反応しないことを認めている18). これは溶媒による反応阻害の唯一の例であり, 詳細は現在検討中 であるが，PCLの活性サイトに溶媒とアルコールが入り込んだ ために起こったものと推察している. 次に, 酵素の熱安定性につ いて調べた. PCL100 mg/mL-sub. soln. で $70^{\circ} \mathrm{C}, 10-18 \mathrm{~h}$ の 加熱では活性の低下は認められなかった． また， $(R)-20.25 \mathrm{M}$, $10.5-1.0 \mathrm{M}$, PCL2 $00 \mathrm{mg} / \mathrm{mL}-\mathrm{sub}$. soln., $30^{\circ} \mathrm{C}$ でベンゼン, シ オキサン, アセトニトリル中で長時間反応させたところ, $c=$ 0.99-0.98で平衡に達し，いずれの場合も100\%の反応は認めら れなかった.これらのデータを用いて平衡定数を求めたところ $K=0.018-0.035$ が得られ，ラセミ体で $c>0.6$ の分割データお よび式 $(1)(c<0.3)$ から求めた $E$ 値から計算した值 ${ }^{220)}(K=$ 0.22-0.30)とほぼ一致しており，反応が 100\%起こらないのは 逆反応のためであることがわかった. 以上のことから, Scheme 1 のエステル交換では PCL は溶媒および温度に対して安定であ り，溶媒分子の反応阻害はないものと結論できた。

溶媒の作用をさらに詳しく検討するため, エナンチオマーの相 対活性 (ヘプタン中 =100)をシクロヘキサン中で測定したところ, $10^{\circ} \mathrm{C}$ では $(R)$ 体で $239,(S)$ 体で $400,50{ }^{\circ} \mathrm{C}$ で $(R)$ 体で 159 , $(S)$ 体で 224 とかさ高い溶媒の方が反応が促進され，その割合は $(S)$ 体の方が大きいことがわかった．この事実から，溶媒分子は 活性サイト(結合サイト)を広げる役割を果たし, 溶媒のかさ高さ は反応の促進(おそらく， R-2 $\rightarrow \mathrm{R}-1$ および $\mathrm{S}-2 \rightarrow \mathrm{S}-1$ の変化)に 寄与しているが，溶媒分子とへキシル基との立体障害のため $(R)$ 体の速度低下は $(S)$ 体よりも大きくなり，全体として $E$ 值が小
さくなるものと考えられる.

活性化エンタルピー $\Delta H^{\ddagger}$ と活性化エネルギー $E_{\mathrm{a}}$ との間には 次の関係が成り立つ。この式から $\Delta \Delta H^{\ddagger}$ はラセミ体中の $(R)$ 体 と

$$
\begin{aligned}
\Delta \Delta H^{\ddagger} & =\Delta H^{\ddagger}(R)-\Delta H^{\ddagger}(S) \\
& =E_{\mathrm{a}}(R)-E_{\mathrm{a}}(S)
\end{aligned}
$$

$(S)$ 体の活性化エネルギーの差を示している. $\Delta \Delta H^{\ddagger}<0$ では $E_{\mathrm{a}}$ $(R)>E_{\mathrm{a}}(S)$ となり, $\Delta \Delta H^{\ddagger}>0$ では $E_{\mathrm{a}}(R)<E_{\mathrm{a}}(S)$ となる. そ こで, $10,50^{\circ} \mathrm{C}$ における初速度定数から活性化エネルギー（誤差 範囲 : $\left.\pm 0.5 \mathrm{~kJ} \mathrm{~mol}^{-1}\right)$ を求めたところ, ヘブタン中では $(R)-2$ で 48.1, (S)-2 で $48.8 \mathrm{~kJ} \mathrm{~mol}^{-1}$ となりエナンチオマーの活性化 エネルギーがほほ等しく，シクロヘキサンでは $(R)-2$ で 40.3, $(S)-2$ で $38.0 \mathrm{~kJ} \mathrm{~mol}^{-1}$ となりかさ高い溶媒では $(R)$ 体の反応の 活性化エネルギーが $(S)$ 体よりも高いこと，トルエン中では $(R)-2$ で 29.4, (S)-2 で $33.8 \mathrm{~kJ} \mathrm{~mol}^{-1}$ であり，(S) 体の活性化エネル ギーが高いことが認められた. さらに，これらの值を用いて式 （6）方計算した $\Delta \Delta H^{\ddagger}$ はヘブタンではー0.7, シクロヘキサン

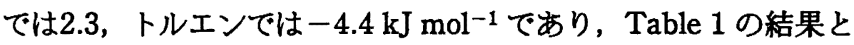
良好な一致が認められた。

反応温度を上げると，活性サイト(結合サイトLP)が広がり， かさ高い溶媒では R-1 配位での溶媒分子とへキシル基との立体 障害が軽减され，(R)-2 が $(S)-2$ よりも速度が促進され $E$ 值が 増加する(Fig. 2) と考えられる. その結果，エナンチ才選択性と $\log P$ との相関珄が $T$ によって変化する(Fig. 1) と解釈できる。

Table 1 から，すへてての場合で $\Delta \Delta S^{\ddagger}>0$ である.これは $(R)$ 体の活性化エントロピーが $(S)$ 体よりも大きいことを示し，前者 の遷移状態が後者よりむ反応に適した状態であること，あるいは 前者が後者よりむ込み合った状態であることを意味している. Fig. 5 のモデルはいずれにも一致しており，本報のデータからは 区別できなかった.

上記の活性化エネルギーのデータで興味ある事実は $(S)-2$ に 対する $(R)-2$ の立体障害が小さいとしたヘブタン中の $E_{\mathrm{a}}(R)$ ， $E_{\mathrm{a}}(S)$ 值がシクロヘキサンよりも大きいことである. 最近の予備 実験の結果から， $E_{\mathrm{a}}$ が 1,2-シクロロエタン>四塩化炭素の順で あり, 溶媒分子の長軸が長い溶媒中の方が活性化エネルギーが大 きいことが認められ，溶媒分子のかさ高さに加えて容積むエナン チオ選択性に関係していることが示唆されている．詳細について は現在検討中である.

以上から，PCL による 1 と 2 (第二級アルコール) とのエステ ル交換のエナンチオ選択性は溶媒の性質・立体構造および反応温 度の組合せによって決定されると結論できた。

\section{4 結論}

PCL 触媒による 1 と 2 との有機溶媒中におけるエステル交换 の溶媒・温度依存性の検討から，エナンチオ選択性は溶媒の疎水 珄に加えて溶媒の立体構造(かさ高さ)や温度（主にエントロピー 効果)に支配されていることがわかった． また， $\log E$ vs. $\log P$ の相関性が反応温度によって変化することを認めた．有機溶媒中 における醇反素を合成に応用するためには，その反応速度とエ ナンチオ選択性が問題となる．エナンチオ選択性の高い 1,2-シ クロロエタン中の反応では，反応温度を $10 \rightarrow 70^{\circ} \mathrm{C}$ 変化に対す る $E$ 值の低下は $20 \%$ 以下であり，反応速度は30 倍以上であるこ 
とから，高温 ${ }^{21)}$ での反応が可能であることがわかった．本報の 結果から, 有機溶媒中における酵素反応のエナンチ才選択性の溶 媒依存性はその性質や構造が単独で作用しているのではなく，反 応温度との組合せによって決定されることがわかった，また，工 ナンチオ選択性に及ほす溶媒の効果を調へるためには活性化パラ メーターを検討することが重要であることが示唆された.

本報の一部は日本化学会北海道支部 1997 年夏季発表会(北見 大会)で発表した．また，本報は1996 年度北海道東海大学研究 · 教育振興基金の助成を受けた

1) A. M. Klibanov, Acc. Chem. Res., 23, 114(1990); E. Santaniello, P. Ferraboschi, G. Grisenti, A. Manzocchi, Chem. Rev., 92, 1071(1992) ; 須貝 威, 土屋滋夫, 望月直樹, 太田博道, 有合化, 53, 32(1995)

2) C.-S. Chen, C. J. Sih, Angew. Chem., Int. Ed. Engl., 28, 695(1989); C.-S. Chen, Y.-C. Liu, J. Jpn. Oil Chem. Soc., 41, 724(1992).

3）苗村浩一郎, 有合化, 52, 49(1994) ; 中村 苝, 広瀬芳彦, 有合化, 53, 668(1995).

4) A. Zaks, A. M. Klibanov, Science, 224, 1249(1984).

5) H. Hirata, K. Higuchi, T. Yamashina, J. Biotechnol., 14, 157(1990) ; 平田博文, 油化学, 39, 1003(1990).

6) a) S. Parida, J. S. Dordick, J. Am. Chem. Soc., 113, 2253 (1991); b) S. Parida, J. S. Dordick, J. Org. Chem., 58, 3238(1993).

7) K. Nakamura, Y. Takebe, T. Kitayama, A. Ohta, Tetrahedron Lett., 32, 4941(1991); H. Hirata, K. Sakaki, T. Yamashina, K. Higuchi, H. Yanagishita, I. Tida, K. Toyota, M. Sugiura, Chem. Express, 7, 293(1992).

8) a) F. Secundo, S. Riva, G. Carrea, Tetrahedron: Asymmetry, 3, 267(1992); b) van T. Pham, R. S. Phillips, L. G. Ljungdahl, J. Am. Chem. Soc., 111, 1935(1989).

9) J. A. Riddick, W. B. Bunger, "Organic Solvents", WileyInterscience, New York, London, Sydney, Toronto (1970),
N， p. 552 ; 畑一夫, 杉山 登, 小林正樹, 大木道則, “化学実験法”, 東京化学同人, 東京 $(1960)$, p. 65.

10) H. Hirata, T. Yamashina, K. Higuchi, K. Sakaki, I. Iida, J. Jpn. Oil Chem. Soc., 40, 995(1991); K. Sakaki, H. Hirata, J. Chromatogr., 585, 117(1991).

11) C.-S. Chen, Y. Fujimoto, G. Girdaukas, C. J. Sih, J. Am. Chem. Soc., 104, 7294(1982); C.-S. Chen, S.-H. Wu, G. Girdaukas, C. J. Sih, J. Am. Chem. Soc., 109, 2812(1987).

12）平田博文, 間山素美, 稲田信之, 山田和徳, 柳下 宏, 杉浦正昭, 油化学, 44, 1067(1995).

13) A. Leo, C. Hansch, D. Elkins, Chem. Rev., 71, 525(1971); R. F. Rekker, "The Hydrophobic Fragment Constants", in "Pharmacochemistry Library, Vol. 1", ed by W. Th. Nauta, R. F. Rekker, Elsevier, Amsterdam-Oxford-New York(1977)

14）これは酵素の結合水 (essential water)が溶媒と固換するこ とにより酵素の立体構造が変化(ただし，小さい)し，その 結果エナンチオ選択性が変化するという考えに基づいてい る.リパーゼ触媒の場合，エナンチオ選択性の溶媒依存性 は複雑であり, 解決すべき問題が多い。

15) T. Sakurai, A. L. Margolin, A. J. Russel, A. M. Klibanov, J. Am. Chem. Soc., 110, 7236(1988).

16) P. A. Fitzpatrick, A. M. Klibanov, J. Am. Chem. Soc., 113, 3166(1991).

17) S. Sakurai, A. M. Klibanov, J. Am. Chem. Soc., 114, 1882 (1992).

18）宮岸正人, 間山素美, 平田博文, 第 36 回油化学討論会, 京都(1997) $2 \mathrm{E} 07$.

19) R. J. Kazlauskas, A. N. E. Weissfloch, A. T. Rappaport, L. A. Cuccia, J. Org. Chem., 56, 2656(1991).

20）平田博文，間山素美，笠原亜弓，柳下 宏，杉浦正昭， 油化学, 45, 761(1996).

21）酵素の結合水は溶媒の共沸点以上では容易に取り除かれ， 活性低下が起こることが知られている5). したがって，有 機溶媒中における醅素反応の温度限界は共沸点(安全のた めには，これより数度低い温度が良い)と考えられる.

\title{
Enantioselectivity of Lipase Catalyzed Transesterification between Tributyrylglycerol and 2-Octanol in Organic Solvents
}

\author{
Hirofumi HiRATA*, Masato MiYAGISHI and Motomi MaYAMA \\ Department of Bioscience and Technology, School of Engineering, Hokkaido Tokai University; \\ 5-1 Minamisawa, Minami-ku, Sapporo-shi 005 Japan
}

Pseudomonas cepacia lipase (PCL) catalyzed transesterification between tributyrylglycerol (1) and 2octanol (2) to give $(R)-1$-methylheptyl butyrate $(3)$ has been studied using eight kinds of organic solvents at $10-70^{\circ} \mathrm{C}$. The enantioselectivity expressed as $\log E$ (where $E$ is the enantiomeric ratio) was negatively correlated with the solvent hydrophobicity $\log P$ (where $P$ is a partition coefficient of a given solvent between octanol and water) except bulky solvents, in which the $\log E$ values were smaller than those expected from $\log P$. The $\log E$ against $\log P$ plot was varied by the reaction temperature $(T)$. The enantioselectivity increased with $T$ for the reaction in the bulky solvents, was independent of $T$ in heptane, and decreased in the others. Activation parameters ( $\Delta \Delta H^{\ddagger}$ and $\Delta \Delta S^{\ddagger}$ ) were determined using a linear correlation between $\Delta \Delta G^{\ddagger}(=-R T \ln E)$ and $T$. The $\Delta \Delta H^{\ddagger}$ values were negative for the reactions in the bulky solvents and positive in the others, and the $\Delta \Delta S^{\ddagger}$ values in the former were larger than those in the latter.

From the above findings, it was concluded that the enantioselectivity was affected by a combination of the nature and structures of the solvent and the reaction temperature. A plausible active site model of PCL was proposed and discussed. 